\title{
Distribution and genomic location of active insertion sequences in the Burkholderia cepacia complex
}

Correspondence
Dervla T. Kenna
dkenna@staffmail.ed.ac.uk

Received 30 May 2005

Accepted 30 August 2005

\author{
Dervla T. Kenna, ${ }^{1} \dagger$ Hasan Yesilkaya, ${ }^{2}$ Ken J. Forbes, ${ }^{3}$ Victoria A. Barcus, ${ }^{1}$ \\ Peter Vandamme ${ }^{4}$ and John R. W. Govan ${ }^{1}$ \\ ${ }^{1}$ Cystic Fibrosis Laboratory, Medical Microbiology, University of Edinburgh, Teviot Place, \\ Edinburgh EH8 9AG, UK \\ ${ }^{2}$ Department of Infection, Immunity and Inflammation, University of Leicester, Maurice Shock \\ Building, University Road, PO Box 138, Leicester LE1 9HN, UK \\ ${ }^{3}$ Department of Medical Microbiology, University of Aberdeen, Foresterhill, Aberdeen AB25 \\ 2ZD, UK \\ ${ }^{4}$ Laboratorium voor Microbiologie, Faculteit Wetenschappen, Universiteit Gent, Ledeganckstraat \\ 35, B-9000, Gent, Belgium
}

\begin{abstract}
This study aimed firstly to establish the distribution and copy number within the Burkholderia cepacia complex of three insertion sequences (IS402, IS407 and IS1416) that possess the ability to activate transcription and hence influence gene expression. A second aim was to map the genomic insertion sites of one of the active insertion sequences (IS407) to establish putative links between insertion site and downstream gene activation. The resulting data revealed that all three insertion sequences were present in one-third of the 66 isolates tested. The three insertion sequences were prevalent across the nine B. cepacia complex species, although IS402 was absent from the 16 Burkholderia anthina strains tested and IS407 was absent from all 10 Burkholderia pyrrocinia strains. IS407 copies from six strains (two Burkholderia cenocepacia strains and one strain each of Burkholderia multivorans, Burkholderia stabilis, Burkholderia vietnamiensis and $B$. anthina) were mapped to the genome using hemi-nested inverse PCR. Insertions were found upstream of genes with wide-ranging functions. This study suggests that the abundance and distribution of these active insertion sequences is likely to affect genomic plasticity, and potentially gene transcription and pathogenicity.
\end{abstract}

\section{INTRODUCTION}

The Burkholderia cepacia complex (Bcc) is composed of a group of highly adaptable bacteria that occupy diverse ecological niches (Coenye \& Vandamme, 2003) and cause life-threatening pulmonary infections in patients with cystic fibrosis (CF) and chronic granulomatous disease (Govan et al., 1996; Sirinavin et al., 2004; Nasser et al., 2004). Polyphasic taxonomy has revealed that the Bcc comprises nine closely related species or genomovars (Coenye et al., 2001). While each of these genomovars has been isolated from CF patients, Burkholderia cenocepacia (formerly genomovar III) and Burkholderia multivorans (formerly

†Present address: Cystic Fibrosis Group, Centre for Infectious Diseases, University of Edinburgh College of Medicine and Veterinary Medicine, The Chancellor's Building, 49 Little France Crescent, Edinburgh EH16 4SB, UK.

Abbreviations: Bcc, Burkholderia cepacia complex; CF, cystic fibrosis; hINVPCR, hemi-nested inverse PCR; IS, insertion sequence. genomovar II) are responsible for approximately $90 \%$ of infections (LiPuma et al., 2001; Mahenthiralingam et al., 2005). Originally identified as a cause of soft rot of onions (Burkholder, 1950), and more recently as a cause of ovine mastitis (Berriatua et al., 2001), the group is also characteristically and intrinsically multidrug-resistant (Nzula et al., 2002).

The molecular and genetic basis for the flexibility of these bacteria has yet to be clarified but should be aided by the annotation of the genome of B. cenocepacia strain J2315 currently underway at the Sanger Centre (http://www. sanger.ac.uk/Projects/B_cenocepacia/). Recent annotation of the closely related species Burkholderia pseudomallei and Burkholderia mallei has emphasized the impact of insertion sequences (ISs) and bacteriophages on both the plasticity and adaptability of these organisms (Holden et al., 2004; Nierman et al., 2004). Furthermore, previous studies have shown that ISs are shared between these highly virulent species and B. cenocepacia (Mack \& Titball, 1998). ISs are 
small, mobile genomic elements possessing only the genes that allow their transposition from one genomic site to another. In addition to their ability to cause genomic rearrangements such as deletions, duplications and recombination, these elements can also insert into genes and promoter regions and may hence affect gene transcription (Wood et al., 1991; Miché et al., 2001; Mahillon \& Chandler, 1998). To date, at least 16 different types of IS have been discovered within the Bcc (Wood et al., 1991; Tyler et al., 1996; Lessie et al., 1996; Miché et al., 2001; Liu et al., 2003), supporting the hypothesis that ISs play a key role in the diversity of these organisms. Of particular interest are active ISs that can upregulate the transcription of genes close to their point of insertion. One of these ISs can affect the transcription of genes involved in adaptation of the Bcc to diverse environmental conditions, thus enabling them to utilize potentially toxic compounds as a carbon source (Hubner \& Hendrickson, 1997). In addition, several studies have demonstrated the in vitro activation of Bcc genes by ISs (Scordilis et al., 1987; Wood et al., 1991; Miché et al., 2001).

To our knowledge, little work has been done on the potential contribution of active ISs to the evolution of Bcc species as opportunistic pathogens for plants, animals and humans, particularly studies that take account of recent developments in the complex taxonomy of these bacteria. In this study, we examined the distribution and copy number of three active ISs (IS402, IS407 and IS1416) in 66 isolates from clinical and environmental sources; the isolates represented all nine genomovars and included six strains with undetermined genomovar status. In addition, IS407 insertion sites of six strains were mapped to the genome and the impact of their insertion on downstream genes considered.

\section{METHODS}

Bacterial strains. Sixty-six strains of both environmental and clinical origin were used in this study. Thirty of these were from the Bcc panel (Mahenthiralingam et al., 2000), 28 were added to represent recently identified genomovars (VI to IX) (Coenye et al., 2003), six strains were found to be of undetermined genomovar status (Peter Vandamme, unpublished data) and two strains were from the Edinburgh Strain Repository. Sixty of these strains were shown to be non-clonal based on PFGE analysis (Butler et al., 1995), four were clones from the ET12 lineage (LMG $16656^{\mathrm{T}}$, LMG 18826, LMG 18863 and LMG 18827) and two B. cepacia strains from different origins were also clonal (ATCC $25416^{\mathrm{T}}$ and C2828).

DNA extraction and PCR. Bacteria were grown overnight at $37^{\circ} \mathrm{C}$ on Columbia-base agar (Oxoid). DNA was extracted using a Puregene DNA isolation kit (Gentra systems), with a few modifications (Kenna et al., 2003). PCR to test for the presence of IS402, IS407 and IS 1416 was conducted using the PCR primers and amplification cycling conditions described by Miché et al. (2001). A $25 \mu \mathrm{l}$ reaction contained the following PCR reagents from Qiagen: $20 \mathrm{ng}$ of DNA, $250 \mu \mathrm{M}$ (each) deoxynucleoside triphosphate, $1.5 \mathrm{mM}$ $\mathrm{MgCl}_{2}, 1 \times$ PCR buffer, 20 pmol each primer (Invitrogen), $1 \mathrm{U}$ Taq polymerase and sterile distilled water. Ten microlitres of PCR product was run alongside a $1 \mathrm{~kb}$ Plus DNA ladder (Invitrogen) on a $1.2 \%$ pre-cast E-gel (Invitrogen). A positive control (the $B$. vietnamiensis type strain LMG $10929^{\mathrm{T}}$ ) that had previously been found to be positive for all three ISs by Miché et al. (2001) was used, and negative controls consisted of PCR reaction mix without DNA.

Southern blotting. Southern blotting was conducted using a digoxigenin (DIG)-labelled probe. Briefly, approximately $2 \cdot 5-4 \mu \mathrm{g}$ DNA was digested at $37^{\circ} \mathrm{C}$ for $4 \mathrm{~h}$ with $10 \mathrm{U}$ BglII, $10 \mathrm{U}$ HindIII or $12 \mathrm{U}$ EcoRI (Promega). DNA was separated on a $0 \cdot 8 \% 0 \cdot 5 \times \mathrm{TBE}$ agarose gel for $16 \mathrm{~h}$ at $1.0 \mathrm{~V} \mathrm{~cm}^{-1}$ alongside $0.05 \mu \mathrm{g}$ DIG-labelled DNA molecular mass marker II (Roche Diagnostics). DNA from the agarose gels underwent Southern blotting transfer via a capillarytransfer method onto a positively charged nylon membrane as described by Sambrook et al. (1989). The IS407 DIG-labelled probe was created using a PCR DIG probe synthesis kit (Roche Diagnostics) with the primers used by Miché et al. (2001) to amplify IS407. The membrane was pre-hybridized with pre-hybridization solution $[5 \times$ SSC, $0 \cdot 1 \%$ N-lauroylsarcosine (w/v), $0.02 \%$ SDS $(\mathrm{w} / \mathrm{v}), 2 \%$ blocking solution $(\mathrm{v} / \mathrm{v})$ (Roche Diagnostics)] in a hybridization bag (Roche Diagnostics) for $4 \mathrm{~h}$ at $68^{\circ} \mathrm{C}$. This step was followed by $12 \mathrm{~h}$ hybridization using $100 \mathrm{ml}$ pre-hybridization buffer and $20 \mu \mathrm{l}$ DIG-labelled probe. All post-hybridization washes were conducted using materials from Roche Diagnostics, unless otherwise stated. Post-hybridization washes consisted of two $5 \mathrm{~min}$ washes at room temperature with $2 \times$ SSC and $0 \cdot 1 \%$ SDS, followed by two $15 \mathrm{~min}$ washes at $68^{\circ} \mathrm{C}$ with pre-heated $0 \cdot 1 \times$ SSC and $0 \cdot 1 \%$ SDS. The membrane was then incubated for $30 \mathrm{~min}$ in blocking solution, followed by 30 min in blocking solution with anti-DIG AP Fab fragments before two 15 min washes in washing buffer and $3 \mathrm{~min}$ in detection buffer. To allow visual detection of the bound probe 20-25 drops of 'CDP* ready-to-use' was added. The membrane was sealed in a hybridization bag and left with Lumi-film chemiluminescent detection film to expose for $2-10 \mathrm{~min}$. Film was processed using an Optimax film processor (Protec Medizintechnik).

Hemi-nested inverse PCR. Hemi-nested inverse PCR (hINVPCR) was carried out, with some modifications, based on a method by Yesilkaya et al. (2003). The main steps of the method are illustrated in Fig. 1. To reach as many insertion sites as possible, both sides of the IS were targeted using primers specific for both the $5^{\prime}$ - and $3^{\prime}$ ends of the IS. Briefly $2 \cdot 5-4 \mu$ g DNA was digested with $5 \mathrm{U}$ of EaeI (New England BioLabs) for $2 \mathrm{~h}$ at $37^{\circ} \mathrm{C}$. Digested DNA was heatinactivated at $65^{\circ} \mathrm{C}$, then self-ligated in a thermal cycler with a heated lid at $16^{\circ} \mathrm{C}$ for $16 \mathrm{~h}$. The ligation mixture consisted of $0 \cdot 5-2 \mu \mathrm{g}$ DNA in $20 \mu \mathrm{l} 10 \times$ ligation buffer [stock: $50 \mathrm{mM}$ Tris/HCl ( $\mathrm{pH} 7 \cdot 6$ ), $10 \mathrm{mM}$ dithioerythritol, $500 \mu \mathrm{g}$ bovine serum albumen $\mathrm{ml}^{-1}$ ] and $4 \mathrm{U} \mathrm{T} 4$ ligase (Roche Diagnostics) made up to a final volume of $200 \mu \mathrm{l}$ with sterile distilled water.

Hemi-nested inverse PCR was carried out as follows. A $50 \mu$ primary PCR reaction was set up exactly as described in the previous section but using $1 \times$ Hot StarTaq PCR buffer, 1.25 U HotStarTaq polymerase (Qiagen) and $5 \mu \mathrm{l}$ circularized DNA. The PCR amplification conditions were as follows: $95^{\circ} \mathrm{C}$ for $15 \mathrm{~min}$, followed by 15 cycles of $94^{\circ} \mathrm{C}$ for $1 \mathrm{~min}, 1 \mathrm{~min}$ at the appropriate annealing temperature using primers for testing either the right side of IS407 (BC4 and BC6) or the left side (BC1 and BC2) (Table 1) and $72{ }^{\circ} \mathrm{C}$ for 2 min and a final extension step of 1 cycle of $72{ }^{\circ} \mathrm{C}$ for $3 \mathrm{~min}$. Two microlitres of primary PCR product was used to set up a $50 \mu \mathrm{l}$ nested PCR reaction. All the other conditions remained the same apart from the primer concentration, which was increased to 60 pmol. The primers used in the nested PCR amplification were BC3 and BC2 (left side of IS407), and BC5 and BC6 (right side of IS407). The PCR amplification conditions were the same as for the primary PCR except that the number of cycles was increased from 15 to 25 . Twelve microlitres of the nested PCR product was electrophoresed for $5 \mathrm{~h}$ at $1.3 \mathrm{~V} \mathrm{~cm}^{-1}$ in a $2 \%$ MetaPhor agarose gel (Cambrex Biosciences). Agarose gels were examined using a UV transilluminator after staining with ethidium 


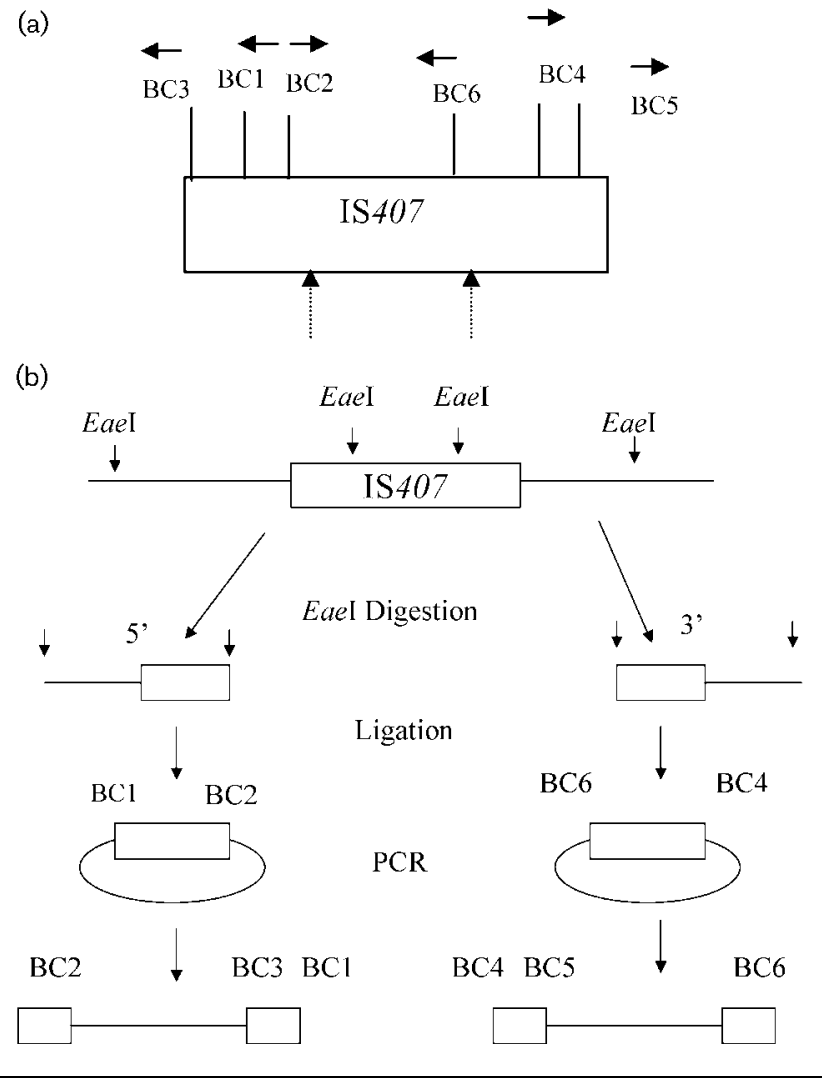

Fig. 1. (a) Position of PCR and sequencing primers in IS407 (black arrows) in relation to Eael restriction sites (black arrows with dotted lines). BC2, BC4 and BC5, forward PCR and sequencing primers; $\mathrm{BC} 1, \mathrm{BC} 3$ and $\mathrm{BC} 6$, reverse $\mathrm{PCR}$ and sequencing primers. (b) Hemi-nested inverse PCR. Genomic DNA was restricted with Eael, heat-inactivated and ligated. The resulting fragments consisted partly of IS407 DNA and partly of IS407-flanking sequence. A primary PCR reaction followed by nested PCR aimed to amplify the region from the end of the IS out to the flanking DNA. DNA was electrophoresed on a $2 \%$ MetaPhor gel and individual bands separated using a band-stabbing technique (Bjourson \& Cooper, 1992). These bands were then purified and the DNA sequenced.

bromide. Bands of interest were separated from one another using a hypodermic needle (BD Microlance 3, Becton Dickinson) as a method of extracting the amplified product from the gel (Bjourson \& Cooper, 1992). The DNA attached to the needle was washed into fresh nested
PCR mix and reamplified. Bands were then purified using a QIAquick PCR purification kit (Qiagen) and sequenced. The sequencing programme was as follows: $95^{\circ} \mathrm{C}$ for $1 \mathrm{~min}$, and 25 cycles of $95^{\circ} \mathrm{C}$ for $30 \mathrm{~s}, 45^{\circ} \mathrm{C}$ for $15 \mathrm{~s}$ and $60^{\circ} \mathrm{C}$ for $4 \mathrm{~min}$. The sequencing mixture consisted of $4 \mu \mathrm{l}$ ABI PRISM BigDye terminator v3.1 cycle sequencing mix (Applied Biosystems), 40 pmol either primer BC2 or primer BC6 and $0 \cdot 35-0 \cdot 8 \mu \mathrm{l}$ DNA, depending on the concentration of DNA. The mixture was made up to $20 \mu \mathrm{l}$ with sterile, distilled water.

DNA sequencing analysis. Vector NTI 8 suite (InforMax) was used for DNA sequence analysis. The raw DNA sequence was checked for the presence of an EaeI restriction site and the IS407 sequence. The flanking DNA sequence was BLAST searched against the Sanger centre J2315 genome sequence (http://www.sanger.ac.uk/ Projects/B_cenocepacia/). Any significant matches (i.e. those with greater than $89 \%$ DNA sequence similarity) were mapped to the genome and $3 \mathrm{~kb}$ regions downstream of the insertion site were BLAST searched using the Institute for Genomic Research database (http://tigrblast.tigr.org/cmr-blast/) or, if no hits were found here, against the database at the National Centre for Biotechnology Research (http://www.ncbi.nlm.nih.gov/blast/) for similarity to known genes. In addition overlapping ORFs were searched for with the Vector NTI software, and the DNA was translated and BLAST searched against the ExPASy database at the Swiss Institute for Bioinformatics (http://ca.expasy.org/).

\section{RESULTS AND DISCUSSION}

\section{Distribution of IS402, IS407 and IS1416 in the study collection}

The first aim of this study was to determine the distribution and copy number of three active ISs (IS402, IS407 and IS1416) across the Bcc including six isolates of undetermined genomovar status. PCR was used to test for the presence of the three ISs in 66 clinical and environmental strains. Thirty-two per cent (21/66) of strains were positive for IS $402,36 \%(24 / 66)$ for IS407 and 35\% (23/66) for IS 1416. The three ISs were found to be distributed across the nine species of the Bcc, with some notable exceptions (Table 2). IS 402 was absent from all 16 strains of $B$. anthina tested, IS407 was absent from all $10 \mathrm{~B}$. pyrrocinia strains and IS1416 was absent from all eight strains of $B$. multivorans. IS 1416 was more common in strains of B. pyrrocinia (8/10, $80 \%)$ and $B$. anthina $(7 / 16,44 \%)$ than in strains from other genomovars. To our knowledge this is the first time that the prevalence of IS1416 has been investigated across the whole Bcc. IS1416 was only recently found to be present in Burkholderia species other than Burkholderia glumae, the

Table 1. Hemi-nested inverse PCR primer sequences and annealing temperatures

\begin{tabular}{|llc|}
\hline Primer & \multicolumn{1}{c|}{ Primer sequence } & Annealing temperature \\
\hline BC1 & $5^{\prime}$-TGCTGTTCCGTAAAGCGCTT-3' & \\
BC2 & $5^{\prime}$-CAAGGACCTCGAGGTGGAGAATGCC-3' & $65^{\circ} \mathrm{C}(\mathrm{BC} 1$ and BC2 $)$ \\
BC3 & $5^{\prime}$-GAACTTTACTAGACTCCGGC-3' & $65^{\circ} \mathrm{C}(\mathrm{BC} 3$ and BC2 $)$ \\
BC4 & $5^{\prime}$-CGGGCAAGCCAACGCAGAAT-3' \\
BC6 & $5^{\prime}$-GTGTGACGCCGTTCGCATAC-3' & \\
BC5 & $5^{\prime}$-GATGCTCCTGCCGCTTTCCA-3' & $60^{\circ} \mathrm{C}(\mathrm{BC} 4$ and BC6 $)$ \\
\end{tabular}


Table 2. Prevalence of IS402, IS407 and IS1416 in the Bcc, and IS407 copy number

Abbreviations: CF, cystic fibrosis; CGD, chronic granulomatous disease; UTI, urinary tract infection.

\begin{tabular}{|c|c|c|c|c|c|}
\hline \multirow[t]{2}{*}{ Strain } & \multirow[t]{2}{*}{ Source } & \multicolumn{3}{|c|}{ Presence/absence of IS } & \multirow{2}{*}{$\begin{array}{l}\text { IS } 407 \text { copy } \\
\text { number }\end{array}$} \\
\hline & & IS 402 & IS407 & IS 1416 & \\
\hline \multicolumn{6}{|l|}{ B. cepacia } \\
\hline ATCC $25416^{\mathrm{T}}$ & Onion, USA & - & - & + & - \\
\hline $\mathrm{C} 2828$ & CF, UK & - & - & + & - \\
\hline LMG 17997 & UTI, Sweden & + & - & - & - \\
\hline LMG 18821 & CF, Australia & - & - & - & - \\
\hline ATCC 17759 & Soil, Trinidad & - & - & - & - \\
\hline \multicolumn{6}{|l|}{ B. multivorans } \\
\hline LMG $13010^{\mathrm{T}}$ & CF, Belgium & - & - & - & - \\
\hline LMG 18825 & $\mathrm{CF}, \mathrm{UK}$ & - & - & - & - \\
\hline LMG 18824 & CGD, USA & - & + & - & 6 \\
\hline LMG 18823 & Lab., USA & + & + & - & $4(1)$ \\
\hline ATCC 17616 & Soil, USA & + & + & - & 4 \\
\hline LMG 16665 & Clinical, UK & - & - & - & - \\
\hline LMG 16660 & CF, UK & - & + & - & 7 \\
\hline LMG 18822 & CF, Canada & - & - & - & - \\
\hline \multicolumn{6}{|l|}{ B. cenocepacia } \\
\hline LMG 16654 & CF, UK & + & - & - & - \\
\hline LMG $16656^{\mathrm{T}} / \mathrm{J} 2315$ & CF, UK & + & + & - & $10(5)$ \\
\hline LMG 16659 & CF, UK & - & - & + & - \\
\hline $\mathrm{C} 2836$ & CF, USA & - & - & - & - \\
\hline LMG 18826/BC7 & CF, Canada & + & + & - & $16(5)$ \\
\hline LMG 18863/K56-2 & CF, Canada & + & + & - & - \\
\hline LMG 18827/C5424 & CF, Canada & + & + & - & 6 \\
\hline LMG 18828 & CF, Canada & + & - & - & - \\
\hline LMG 18829 & CF, USA & + & - & + & - \\
\hline LMG 18830 & CF, Australia & + & - & - & - \\
\hline ATCC 17765 & UTI, UK & - & + & + & 3 \\
\hline \multicolumn{6}{|l|}{ B. stabilis } \\
\hline LMG $14294^{\mathrm{T}}$ & $\mathrm{CF}$, Belgium & + & + & - & $10(4)$ \\
\hline LMG 18870 & CF, Canada & + & + & - & 5 \\
\hline LMG 18888 & Clinical, Belgium & - & - & - & - \\
\hline LMG 14086 & Clinical, UK & - & - & - & - \\
\hline \multicolumn{6}{|l|}{ B. vietnamiensis } \\
\hline LMG 16232 & CF, Sweden & + & + & - & $9(9)$ \\
\hline LMG 18835 & CF, USA & + & - & - & - \\
\hline LMG 18836 & CGD, Canada & + & + & + & 7 \\
\hline LMG $10929^{\mathrm{T}}$ & Rice, Vietnam & + & + & + & 3 \\
\hline \multicolumn{6}{|l|}{ B. dolosa } \\
\hline LMG 21820 & CF, UK & + & - & - & - \\
\hline \multicolumn{6}{|l|}{ B. ambifaria } \\
\hline LMG $19182^{\mathrm{T}}$ & Soil, USA & + & - & + & - \\
\hline \multicolumn{6}{|l|}{ B. anthina } \\
\hline LMG 16670 & Rhizosphere, UK & - & + & - & 7 \\
\hline J2553 & Soil, UK & - & - & - & - \\
\hline LMG $20980^{\mathrm{T}}$ & Soil, USA & - & - & - & - \\
\hline J2927 & Soil, UK & - & + & + & 3 \\
\hline J2928 & Soil, UK & - & + & + & 3 \\
\hline J2941 & Rhizosphere, UK & - & + & + & 6 \\
\hline $\mathrm{J} 2943$ & Rhizosphere, UK & - & - & - & - \\
\hline J2944 & Rhizosphere, UK & - & + & + & $3(1)$ \\
\hline $\mathrm{J} 2945$ & Rhizosphere, UK & - & + & + & 3 \\
\hline
\end{tabular}


Table 2. cont.

\begin{tabular}{|c|c|c|c|c|c|}
\hline \multirow[t]{2}{*}{ Strain } & \multirow[t]{2}{*}{ Source } & \multicolumn{3}{|c|}{ Presence/absence of IS } & \multirow{2}{*}{$\begin{array}{c}\text { IS407 copy } \\
\text { number }^{*}\end{array}$} \\
\hline & & IS402 & IS407 & IS 1416 & \\
\hline J2946 & Rhizosphere, UK & - & + & + & 2 \\
\hline$J 2949$ & Rhizosphere, UK & - & - & - & - \\
\hline $\mathrm{J} 2950$ & Rhizosphere, UK & - & + & + & 3 \\
\hline$J 2951$ & Rhizosphere, UK & - & - & - & - \\
\hline $\mathrm{J} 2862$ & Rhizosphere, UK & - & - & - & - \\
\hline LMG 20982 & Environmental, UK & - & - & - & - \\
\hline LMG 20983 & CF, UK & - & - & - & - \\
\hline \multicolumn{6}{|c|}{ B. pyrrocinia } \\
\hline $\mathrm{J} 2536$ & Soil, UK & - & - & + & - \\
\hline $\mathrm{J} 2542$ & Soil, UK & - & - & + & - \\
\hline LMG 21824 & CF, UK & - & - & + & - \\
\hline C3909 & Clinical, Italy & - & - & + & - \\
\hline C3918 & Clinical, Italy & + & - & + & - \\
\hline C3928 & Clinical, Italy & - & - & + & - \\
\hline C3930 & Clinical, Italy & - & - & - & - \\
\hline C3993 & Clinical, Italy & - & - & + & - \\
\hline C3995 & Clinical, Italy & - & - & + & - \\
\hline C3997 & Clinical, Italy & - & - & - & - \\
\hline \multicolumn{6}{|c|}{$\begin{array}{l}\text { Genomovar status } \\
\text { undetermined }\end{array}$} \\
\hline E26 & CF, UK & - & + & - & 3 \\
\hline E27 & CF, UK & - & + & - & 3 \\
\hline E571 & CF, UK & - & - & - & - \\
\hline E551 & CF, UK & - & - & - & - \\
\hline$J 2956$ & Ovine, Spain & + & - & - & - \\
\hline LMG 16672 & Soil, UK & - & - & - & - \\
\hline
\end{tabular}

${ }^{*}$ Numbers in parentheses indicate the number of IS407 copies successfully mapped to the Sanger Centre J2315 sequence for the six strains tested using hemi-nested inverse PCR.

species with which it was first associated (Miché et al., 2001; Hasebe et al., 1998).

Due to the small number of Burkholderia dolosa and Burkholderia ambifaria strains available, it was not initially possible to draw conclusions about the IS distribution in strains from these species. However, additional strains from the extended Bcc panel (Coenye et al., 2003) were later acquired and tested with the same primers. The three additional $B$. dolosa strains tested were negative for all three ISs, and of the three additional B. ambifaria strains tested, only one was positive for the presence of an IS (IS407). The data in Table 2 suggested that IS 407 might be uncommon or absent in B. cepacia (previously genomovar I). However, when an additional six B. cepacia strains were tested, five were positive for IS407. Likewise all eight strains of $B$. multivorans were negative for IS1416, but unlike the previous example, when an additional four B. multivorans strains were tested these were all negative also. Overall, our data support previous reports that different Burkholderia species possess different active IS elements (Hasebe et al., 1998; Miché et al., 2001).
The only IS to show a different distribution between clinical and environmental strains was IS402, which was present in $41 \%(17 / 41)$ of clinical isolates, but in only $17 \%(4 / 24)$ of environmental isolates. However, it should be noted that there was no balance between clinical and environmental isolates in each of the Bcc species. Both IS407 and IS 1416 were relatively evenly distributed between clinical and environmental strains, with IS 407 present in $46 \%(11 / 24)$ of environmental strains and $32 \%(13 / 41)$ of clinical strains, while IS 1416 was found in $50 \%(12 / 24)$ of environmental strains and $27 \%(11 / 41)$ of clinical strains. The only animal isolate in this study was from a sheep suffering from subclinical mastitis (Berriatua et al., 2001) and this strain was found to have only one of the three IS elements (IS402).

\section{Copy-number variation of IS407}

In our study, we decided that IS407 should be examined in more detail to determine copy-number variation amongst the different genomovars. IS407 was chosen because of its well-established mechanism for gene activation, which works on the basis of the outwardly directed $\sigma^{70}$-like 
promoter within its IR-R (an inverted repeat at the right end of the IS) (Wood et al., 1991). In addition, of the three ISs that were tested by PCR, IS407 was found to be the most common IS in J2315. Initial BLAST analysis of the J2315 sequence from the Sanger centre revealed that there were 13 copies of IS407: 10 copies on chromosome 1, one copy on the plasmid and one each on chromosomes 2 and 3.

Genomic DNA from 23 IS407-positive strains was digested and the IS407 copy number determined using Southern blotting. Three restriction enzymes (BglII, HindIII and EcoRI) were used to allow accurate coverage of the genome of the Bcc, which has been shown to vary in size from $5 \mathrm{Mb}$ to just over $9 \mathrm{Mb}$ (Lessie et al., 1996). The copy number ranged from two to 16 with a mean of five, which was in agreement with the range noted by others (Mack \& Titball, 1998; Miché et al., 2001). There seemed to be a greater number of IS 407 copies in isolates of B. cenocepacia than in other species, especially $B$. anthina (a mean of $8 \cdot 75$, compared to $3 \cdot 75$, respectively). A disparity between the clonal ET12 B. cenocepacia strains J2315, BC7 and C5424 was found on Southern blotting. The ET12 lineage predominates among CF patients in Canada and the UK (Govan et al., 1993), and, though clonal, reports of morphological differences and variation in antibiotic sensitivities between these strains have been noted elsewhere (Winstanley et al., 2001; Nzula et al., 2002). In this study, BC7 was found to have 16 copies while BLAST analysis found J2315 to have 13 (although this laboratory found only 10) and C5424 had only six (Fig. 2). Likewise, the study by Mack \& Titball (1998) found only eight copies for J2315. Perhaps restrictions with a wider variety of enzymes would be necessary before all copies could be successfully identified. Alternatively, perhaps IS407 copy-number variation does exist between these strains. K56-2 was only found to be positive for IS 407 when this study was nearing completion, thus no blotting data exist for this strain.

Interestingly, towards the completion of these studies, Ortega et al. (2005) found evidence of further differences between these clonal strains. The authors showed that the interruption, by IS402, of a predicted glycosyltransferase gene in the $\mathrm{O}$ antigen LPS biosynthesis gene cluster correlates with the loss of LPS $\mathrm{O}$ antigen in J2315. In addition, the presence of an unusual prophage element encoding phage DK4/BCepMu (Summer et al., 2004; Langley et al., 2003) in J2315 but not K56-2 is also associated with possession of an LPS glycosyltransferase gene. It is tempting to speculate that the presence of IS402 within the prophage interrupts glycosyltransferase activity in J2315, leading to loss of O antigen and increased endotoxicity.

\section{IS407 insertion site mapping}

The second aim of this study was to map IS407 to the genome to establish putative links between insertion site and downstream gene transcription. IS407 insertion sites from six IS407-positive strains (B. cenocepacia LMG 18826, B. cenocepacia LMG $16656^{\mathrm{T}}$, B. multivorans LMG 18823 , B. stabilis LMG $14294^{\mathrm{T}}$, B. vietnamiensis LMG 16232 and $B$. anthina J2944) were identified by hINVPCR and mapped to the genome. These results are summarized in Table 3. In



Fig. 2. Southern blot of $B$. cepacia complex DNA digested with EcoRI showing the differences in IS407 copy number between the clonal ET12 B. cenocepacia strains C5424, $\mathrm{BC7}$ and J2315 (lanes 7, 9 and 10, respectively). Lanes 1-15: LMG 16670, LMG 18836, LMG 16232, ATCC 17765, LMG 18870, LMG 14294, LMG 18827/C5424, DIG-labelled DNA molecular mass marker II, LMG 18826/BC7, LMG 16656 ${ }^{\top} / \mathrm{J} 2315$, LMG 16660, ATCC 17616, LMG 18823, LMG 18824 and DIG-labelled DNA molecular mass marker II, respectively. 
Table 3. Data analysis of IS 407 sequencing results

\begin{tabular}{|c|c|c|c|}
\hline Strain (species) & $\begin{array}{c}{ }^{*} \text { Sanger Centre J2315 } \\
\text { database matches (position) }\end{array}$ & $\begin{array}{l}\text { Flanking DNA sequence matches } \\
\text { in TIGR database (accession number) }\end{array}$ & $\begin{array}{c}\dagger \text { Translated overlapping ORFs in flanking sequence } \\
\text { with matches to ExPASy database (accession number) }\end{array}$ \\
\hline $\begin{array}{l}\text { LMG } 18826 \\
\text { (B. cenocepacia) } \\
\text { LMG } 16656^{\mathrm{T}} \\
\text { (B. cenocepacia) } \\
\text { LMG } 14294^{\mathrm{T}} \\
\text { (B. stabilis) }\end{array}$ & Plus strand - plasmid (81053) & $\begin{array}{l}\text { High number of matches to aldehyde dehydrogenase } \\
\text { and carbamoyl transferase proteins ( } 60 \% \text { match to } B \text {. } \\
\text { mallei aldehyde dehydrogenase family) (BMA0347) }\end{array}$ & $\begin{array}{l}17 \text { ORFs; ORF1 ( } 40 \mathrm{bp} \text { from IS site) }-53 \% \text { match to a } \\
\text { probable carbamoyl transferase-Leptospira interrogans (Q8F5P8) }\end{array}$ \\
\hline $\begin{array}{l}\text { LMG } 18826 \\
\text { (B. cenocepacia) }\end{array}$ & $\begin{array}{l}\text { Minus strand - chromosome } \\
1(6422367)\end{array}$ & $\begin{array}{l}84 \% \text { match to putative outer membrane porin } \\
\text { protein of B. mallei (BMA3345) }\end{array}$ & $\begin{array}{l}16 \text { ORFs; ORF1 ( } 50 \mathrm{bp} \text { from IS site) }-59 \% \text { match to an } \\
\text { outer membrane porin protein-Bordetella parapertussis } \\
\text { (Q7W3G1); ORF6 ( } 850 \text { bp from IS site) }-52 \% \text { match to } \\
\text { glutathione reductase-Bradyrhizobium japonicum (Q89NS7) }\end{array}$ \\
\hline $\begin{array}{l}\text { LMG } 18826 \\
\text { (B. cenocepacia) }\end{array}$ & $\begin{array}{l}\text { Plus strand - chromosome } 2 \\
(2117361)\end{array}$ & $\begin{array}{l}\sim 700 \text { bp from IS }-60 \% \text { match to putative } \\
\text { proline-rich transmembrane protein-Ralstonia } \\
\text { solanacearum (RSc3315), } 55 \% \text { match to putative } \\
\text { lipoprotein- } B \text {. mallei (BMAA0399) }\end{array}$ & $\begin{array}{l}6 \text { ORFs; ORF } 2 \text { ( } 600 \mathrm{bp} \text { from IS site) - high number of } \\
\text { matches to phage proteins, including a } 24 \% \text { match to a } \\
\text { phage protein of B. cenocepacia BcepBIA (Q6IWQ1) }\end{array}$ \\
\hline $\begin{array}{l}\text { LMG } 18826 \\
\text { (B. cenocepacia) }\end{array}$ & $\begin{array}{l}\text { Plus strand - chromosome } 1 \\
(2873471)\end{array}$ & $\begin{array}{l}83 \% \text { match to putative outer membrane porin } \\
\text { protein from B. mallei (BMA0743) }\end{array}$ & $\begin{array}{l}5 \text { ORFs; ORF1 ( } 220 \text { bp from IS site) }-32 \% \text { match to a } \\
\text { probable outer membrane porin lipoprotein transmembrane- } \\
\text { Ralstonia solanacearum (Q8Y009); ORF5 ( } 890 \text { bp from IS } \\
\text { site) }-74 \% \text { match to a probable nitrogen regulatory PII } \\
\text { transcriptional regulator protein- } R \text {. solanacearum (Q8XWX5); } \\
\text { ORF6 ( } 1310 \text { bp from IS site) }-62 \% \text { match to a probable } \\
\mathrm{NH}_{3} \text {-dependent NAD + synthetase signal peptide protein } \\
\text { (nadE)-R. solanacearum (Q8XWX3) }\end{array}$ \\
\hline $\begin{array}{l}\text { LMG } 18826 \\
\text { (B. cenocepacia) } \\
\text { LMG } 16656^{\mathrm{T}} \\
\text { (B. cenocepacia) }\end{array}$ & $\begin{array}{l}\text { Plus strand - chromosome } 1 \\
(450374)\end{array}$ & No matches & 7 ORFs; no significant matches \\
\hline $\begin{array}{l}\text { LMG } 16656^{\mathrm{T}} \\
\text { (B. cenocepacia) }\end{array}$ & $\begin{array}{l}\text { Plus strand - chromosome } 1 \\
(2800416)\end{array}$ & $\begin{array}{l}\text { High number of matches to transcriptional } \\
\text { regulators, including } 59 \% \text { match to a probable } \\
\text { transcriptional regulator- } R \text {. solanacearum } \\
\text { (RSp1146) }\end{array}$ & $\begin{array}{l}10 \text { ORFs; ORF } 3 \text { ( } 1771 \mathrm{bp} \text { from IS site) - many matches to } \\
\text { transcriptional regulators; highest match, } 38 \% \text { match to LysR } \\
\text { transcriptional regulator from Bordetella pertussis (Q7VTR6); } \\
\text { ORF } 8 \text { ( } 1641 \text { bp from IS site) - } 48 \% \text { match to putative } \\
\text { hydrolase from Streptomyces avermitilis, also high number of } \\
\text { matches to other hydrolases including Pseudomonas syringae } \\
\text { pv. tomato (Q87XT7) }\end{array}$ \\
\hline $\begin{array}{l}\text { LMG } 16656^{\mathrm{T}} \\
\text { (B. cenocepacia) }\end{array}$ & $\begin{array}{l}\text { Plus strand - chromosome } 1 \\
(1417058)\end{array}$ & $\begin{array}{l}\text { High number of matches to transposases, including } \\
\text { transposases of Geobacter sulfurreducens and } P . \\
\text { syringae }\end{array}$ & $\begin{array}{l}8 \text { ORFs; ORF } 7 \text { ( } 2851 \mathrm{bp} \text { from the IS site) }-61 \% \text { match to a } \\
\text { putative transposition helper protein from Salmonella enterica } \\
\text { subspecies Enterica serovar cubana (Q8RNK7); ORF } 8 \text { ( } 3111 \mathrm{bp} \\
\text { from the IS site) - } 43 \% \text { match to ISPsy4 transposase from } P \text {. } \\
\text { syringae pv. tomato (Q877U4) }\end{array}$ \\
\hline
\end{tabular}




\begin{tabular}{|c|c|c|c|}
\hline Strain (species) & $\begin{array}{c}{ }^{\star} \text { Sanger Centre } \mathrm{J} 2315 \\
\text { database matches (position) }\end{array}$ & $\begin{array}{l}\text { Flanking DNA sequence matches } \\
\text { in TIGR database (accession number) }\end{array}$ & $\begin{array}{l}\dagger \text { Translated overlapping ORFs in flanking sequence } \\
\text { with matches to ExPASy database (accession number) }\end{array}$ \\
\hline $\begin{array}{l}\text { LMG } 16656^{\mathrm{T}} \\
\text { (B. cenocepacia) }\end{array}$ & $\begin{array}{l}\text { Plus strand - chromosome } 1 \\
(352537)\end{array}$ & $\begin{array}{l}59 \% \text { match to 2-oxoglutarate dehydrogenase E1 } \\
\text { component-Bordetella bronchiseptica (BB3669) }\end{array}$ & 9 ORFs; no significant matches \\
\hline $\begin{array}{l}\text { LMG } 18823 \\
(\text { B. multivorans })\end{array}$ & No matches & $\begin{array}{l}\$ 98 \% \text { match to NADH-dependent flavin } \\
\text { oxidoreductase-Pseudomonas putida (AE016783) }\end{array}$ & $\begin{array}{l}3 \text { ORFs; ORF } 1 \text { ( } 24 \text { bp from IS site) }-100 \% \text { match to NADH- } \\
\text { dependent flavin oxidoreductase from } P \text {. putida (Q88K07) }\end{array}$ \\
\hline $\begin{array}{l}\text { LMG } 14294^{\mathrm{T}} \\
\text { (B. stabilis) }\end{array}$ & $\begin{array}{l}\text { Minus strand - chromosome } \\
1(460752)\end{array}$ & $\begin{array}{l}61 \% \text { match to restriction enzyme type I helicase } \\
\text { subunits and hsdR-Nitrosomonas europaea }\end{array}$ & 15 ORFs; no significant matches \\
\hline $\begin{array}{l}\mathrm{LMG} 14294^{\mathrm{T}} \\
\quad(\text { B. stabilis })\end{array}$ & $\begin{array}{l}\text { Plus strand - } \\
\text { chromosome } 3 \text { (817701) }\end{array}$ & $\begin{array}{l}\sim 1 \text { bp after IS site }-100 \% \text { identity to } 5 \text { S rRNA-Bcc } \\
(\text { X02629); } \sim 120 \text { bp from IS site }-100 \% \text { match to } \\
23 \mathrm{~S} \text { rRNA-Bcc }(\text { X16368); } \sim 2 \cdot 1 \mathrm{~kb} \text { from IS site - } \\
99 \% \text { identity to } 16 \mathrm{~s} \text { rRNA-Bcc (L28154) } \ddagger\end{array}$ & $\begin{array}{l}7 \text { ORFS; ORF } 3 \text { ( } 937 \text { bp from IS site) } 75 \% \text { match (with start of } \\
\text { sequence only) to cell wall-associated hydrolase from Vibrio } \\
\text { vulnificus (Q8CME1); ORF } 4 \text { (1963 bp from IS site) }-50 \% \\
\text { match to the hypothetical protein from Deinococcus radiodurans } \\
\text { (Q9RXQ4) }\end{array}$ \\
\hline $\begin{array}{l}\text { LMG } 14294^{\mathrm{T}} \\
(\text { B. stabilis })\end{array}$ & $\begin{array}{l}\text { Plus strand - chromosome } 3 \\
(817699)\end{array}$ & $\begin{array}{l}58 \% \text { match to conserved hypothetical protein- } \\
\text { Streptomyces coelicolor (SCO5040) }\end{array}$ & 11 ORFs; no significant matches \\
\hline $\begin{array}{l}\text { LMG } 16232 \\
\text { (B. vietnamiensis })\end{array}$ & No matches & $\begin{array}{l}73 \% \text { match to UDP-glucuronic acid epimerase (IspL) } \\
\text { from Bradyrhizobium japonicum (r2382) }\end{array}$ & No ORFs \\
\hline $\begin{array}{l}\text { LMG } 16232 \\
\text { (B. vietnamiensis) }\end{array}$ & No matches & $\begin{array}{l}70 \% \text { match to DNA helicase-Agrobacterium tumefaciens } \\
\text { (AGR_C_92) }\end{array}$ & 3 ORFs; no significant matches \\
\hline $\begin{array}{l}\text { LMG } 16232 \\
(\text { B. vietnamiensis })\end{array}$ & No matches & $\begin{array}{l}66 \% \text { match to putative integrase/recombinase protein } \\
\text { from } R . \text { solanacearum (RSc1554) }\end{array}$ & $\begin{array}{l}5 \text { ORFs; ORF } 2 \text { ( } 23 \mathrm{bp} \text { from IS site) }-80 \% \text { match to putative } \\
\text { integrase/recombinase protein from } R \text {. solanacearum (Q8XZ52); } \\
\text { high matches to other site-specific recombinases, phage } \\
\text { integrase family }\end{array}$ \\
\hline $\begin{array}{l}\text { LMG } 16232 \\
\text { (B. vietnamiensis })\end{array}$ & No matches & $\begin{array}{l}70 \% \text { match to lysyl-tRNA synthetase-Bdellovibrio } \\
\text { bacteriovorus (Bd0702) }\end{array}$ & 2 ORFs; no significant matches \\
\hline $\begin{array}{l}\text { LMG } 16232 \\
\text { (B. vietnamiensis })\end{array}$ & No matches & $\begin{array}{l}70 \% \text { match to arabinofuranosidase (abfB)-S. coelicolor } \\
\text { (SCO5932) }\end{array}$ & 2 ORFs; no significant matches \\
\hline $\begin{array}{l}\text { LMG } 16232 \\
\text { (B. vietnamiensis) }\end{array}$ & No matches & $\begin{array}{l}64 \% \text { match to comED-non-essential protein-Bacillus } \\
\text { subtilis (Bsu2556) }\end{array}$ & 5 ORFs; no significant matches \\
\hline $\begin{array}{l}\text { LMG } 16232 \\
\text { (B. vietnamiensis) }\end{array}$ & No matches & $\begin{array}{l}67 \% \text { match to a hypothetical protein-Xylella fastidiosa } \\
(\mathrm{XF} 0715)\end{array}$ & Not enough flanking sequence to look for ORFs \\
\hline $\begin{array}{l}\text { LMG } 16232 \\
\text { (B. vietnamiensis })\end{array}$ & No matches & $\begin{array}{l}61 \% \text { match to molybdopterin biosynthesis protein } \\
\text { MoeA-Chlorobium tepidum (CT1331) }\end{array}$ & 1 ORF; no significant matches \\
\hline $\begin{array}{l}\text { LMG } 16232 \\
\text { (B. vietnamiensis) }\end{array}$ & No matches & $\begin{array}{l}74 \% \text { match to a hypothetical protein- } R . \text { solanacearum } \\
\text { (RSp0512) }\end{array}$ & 2 ORFs; no significant matches \\
\hline $\mathrm{J} 2944$ (B. anthina) & No matches & $\begin{array}{l}66 \% \text { match to a putative maltooligosyl trehalose } \\
\text { trehalohydrolase protein- } R \text {. solanacearum (RSp0512) }\end{array}$ & No ORFs \\
\hline
\end{tabular}

${ }^{*}$ Only DNA sequences that gave $\geqslant 89 \%$ match with the J2315 sequence at the Sanger Centre were considered to be positive matches. All sequences with lower matches were not classed as matches. $\dagger$ In cases where the flanking sequence matched that of J2315 flanking sequence ORFs $3 \mathrm{~kb}$ downstream were searched for and BLAST searched against the ExPASy database. In cases where this was not possible, existing flanking sequence was checked.

이 ¥Matches found using National Centre for Biotechnology Research database (http://www.ncbi.nlm.nih.gov/blast/). 
some cases, only a few of the copies from each strain were successfully mapped.

Previous studies have suggested that active ISs generally affect the transcription of genes directly next to their insertion site (Reynolds et al., 1981). IS403, however, was found to have more far-reaching effects at $>700$ bp downstream from the insertion site (Scordilis et al., 1987; Wood et al., 1991). Although Miché et al. (2001) found that certain IS407 insertions were at the $3^{\prime}$ end of the genes examined in their study, it was acknowledged that in general these ISs affect genes downstream of their insertion site. Since it is not clear how far from its insertion site IS 407 can act, the flanking sequence $3 \mathrm{~kb}$ downstream of the IS site was BLAST searched.

In general, flanking sequences could not be matched to one particular gene family but rather to genes with a range of different functions (Table 3). In some cases, matches were found to putative regulatory genes such as transcriptional regulators and methylases, but also to housekeeping genes such as those involved in amino acid synthesis, aromatic compound metabolism and disulphide oxidoreductase activity. Several matches were also found to putative outer membrane porin genes and also to genes encoding transmembrane proteins. In all, there did not seem to be a link to a particular gene family, suggesting that the presence of IS407 affects potential virulence factors but also upregulation of genes crucial to cell survival as noted elsewhere for the $\beta$-lactamase genes of the Bcc (Scordilis et al., 1987). Indeed, it seems likely that IS407 inserts at random locations in the genome. Although it is hard to be certain without testing a greater number of strains, there did not seem to be any evidence of a preferential locus for insertion, as has been found for IS6110 in Mycobacterium tuberculosis (which, like IS 407, is a member of the IS 3 family of ISs) (Fang \& Forbes, 1997).

Interestingly, from the perspective of flanking sequence matches to J2315, two strains, LMG 18826 (BC7) and LMG $14294^{\mathrm{T}}$ (Burkholderia stabilis) had identical sequence matches to the Sanger centre strain (five of the 16 BC7 IS 407 copies that were successfully sequenced were mapped to J2315 and likewise four of the 10 IS 407 copies from LMG $\left.14294^{\mathrm{T}}\right)$. While it is understandable that both the clonal ET12 strains J2315 and BC7 would share sequence homology, it is interesting that a $B$. stabilis strain would have the same level of similarity to J2315. However, perhaps the flanking sequence for the six IS407 copies that were not successfully sequenced in this study would not exhibit a high level of similarity to J2315, thus giving a deceptive impression of overall genome similarity. It is, however, interesting that strain LMG 16232 (B. vietnamiensis), the strain most successfully amplified by hINVPCR (flanking sequence for all nine copies was sequenced), showed no matches to the J2315 genome. Likewise, neither did flanking sequences from strains LMG 18823 (B. multivorans) and J2944 (B. anthina), although for both these strains only one of each of the IS407 copies was successfully sequenced.

\section{Conclusions}

In conclusion, with some interesting exceptions, this study has shown that the three active ISs IS402, IS407 and IS 1416 are distributed across the nine species of the Bcc. IS 407 copies from six strains were mapped to the genome and were found to have inserted upstream of a wide range of putative housekeeping, informational and hypervariable genes including genes involved in amino acid synthesis, transcriptional regulation and outer-membrane proteins. A fuller analysis of the hemi-nested inverse PCR results will be made easier by the completed annotation of the J2315 genome sequence. A closer look at genomic regions of interest will also help to determine the impact of active ISs on the diversity and variable virulence within the Bcc.

\section{ACKNOWLEDGEMENTS}

We are indebted to the UK Cystic Fibrosis Trust for financial support for this study. In addition we would also like to thank Julian Parkhill at the Sanger Centre for letting us use their sequencing data, and G. Einarrson and A. Montazam at the ICMB automated sequencing service at the University of Edinburgh.

\section{REFERENCES}

Berriatua, E., Ziluaga, I., Miguel-Virto, C., Uribarren, P., Juste, R., Laevens, S., Vandamme, P. \& Govan, J. R. (2001). Outbreak of subclinical mastitis in a flock of dairy sheep associated with Burkholderia cepacia complex infection. J Clin Microbiol 39, 990-994.

Bjourson, A. J. \& Cooper, J. E. (1992). Band stab PCR: a simple technique for the purification of individual PCR products. Nucleic Acids Res 20, 4675.

Burkholder, W. H. (1950). Sour skin, a bacterial rot of onion bulbs. Phytopathology 40, 115-117.

Butler, S. L., Doherty, C. J., Hughes, J. E., Nelson, J. W. \& Govan, J. R. W. (1995). Burkholderia cepacia and cystic fibrosis: do natural environments present a potential hazard? J Clin Microbiol 33, 1001-1004.

Coenye, T. \& Vandamme, P. (2003). Diversity and significance of Burkholderia species occupying diverse ecological niches. Environ Microbiol 5, 719-729.

Coenye, T., Vandamme, P., Govan, J. R. \& LiPuma, J. J. (2001). Taxonomy and identification of the Burkholderia cepacia complex. J Clin Microbiol 39, 3427-3436.

Coenye, T., Vandamme, P., LiPuma, J. J., Govan, J. R. \& Mahenthiralingam, E. (2003). Updated version of the Burkholderia cepacia complex experimental strain panel. J Clin Microbiol 41, 2797-2798.

Fang, Z. \& Forbes, K. J. (1997). A Mycobacterium tuberculosis IS6110 preferential locus $(i p l)$ for insertion into the genome. J Clin Microbiol 35, 479-481.

Govan, J. R., Brown, P. H., Maddison, J., Doherty, C. J., Nelson, J. W., Dodd, M., Greening, A. P. \& Webb, A. K. (1993). Evidence for transmission of Pseudomonas cepacia by social contact in cystic fibrosis. Lancet 342, 15-19.

Govan, J. R. W., Hughes, J. E. \& Vandamme, P. (1996). Burkholderia cepacia: medical, taxonomic and ecological issues. J Med Microbiol 45, 395-407. 
Hasebe, A., Tsushima, S. \& Lida, S. (1998). Isolation and characterisation of IS1416 from Pseudomonas glumae, a new member of the IS3 family. Plasmid 39, 196-204.

Holden, M. T. G., Titball, R. W., Peacock, S. J. \& 45 other authors (2004). Genomic plasticity of the causative agent of melioidosis, Burkholderia pseudomallei. Proc Natl Acad Sci U S A 101, 14240-14245.

Hubner, A. \& Hendrickson, W. (1997). A fusion promoter created by a new insertion sequence, IS1490, activates transcription of 2,4,5trichlorophenoxyacetic acid catabolic genes in Burkholderia cepacia AC1100. J Bacteriol 179, 2717-2723.

Kenna, D. T., Barcus, V. A., Langley, R. J., Vandamme, P. \& Govan, J. R. (2003). Lack of correlation between O-serotype, bacteriophage susceptibility and genomovar status in the Burkholderia cepacia complex. FEMS Immunol Med Microbiol 35, 87-92.

Langley, R., Kenna, D. T., Vandamme, P., Ure, R. \& Govan, J. R. (2003). Lysogeny and bacteriophage host range within the Burkholderia cepacia complex. J Med Microbiol 52, 483-490.

Lessie, T. G., Hendrickson, W., Manning, B. \& Devereux, R. (1996). Genomic complexity and plasticity of Burkholderia cepacia. FEMS Microbiol Lett 144, 117-128.

LiPuma, J. J., Spilker, T., Gill, L. H., Campbell, P. W., III, Liu, L. \& Mahenthiralingam, E. (2001). Disproportionate distribution of Burkholderia cepacia complex species and transmissibility markers in cystic fibrosis. Am J Respir Crit Care Med 164, 92-96.

Liu, L., Spilker, T., Coenye, T. \& LiPuma, J. J. (2003). Identification by subtractive hybridisation of a novel insertion element specific for two widespread Burkholderia cepacia genomovar III strains. J Clin Microbiol 41, 2471-2476.

Mack, K. \& Titball, R. W. (1998). The detection of insertion sequences within the human pathogen Burkholderia pseudomallei which have been identified previously in Burkholderia cepacia. FEMS Microbiol Lett 162, 69-74.

Mahenthiralingam, E., Coenye, T., Chung, J. W., Speert, D. P., Govan, J. R., Taylor, P. \& Vandamme, P. (2000). Diagnostically and experimentally useful panel of strains from the Burkholderia cepacia complex. J Clin Microbiol 38, 910-913.

Mahenthiralingam, E., Urban, T. A. \& Goldberg, J. B. (2005). The multifarious, multireplicon Burkholderia cepacia complex. Nature Rev Microbiol 3, 144-156.

Mahillon, J. \& Chandler, M. (1998). Insertion sequences. Microbiol Mol Biol Rev 62, 725-774.

Miché, L., Faure, D., Blot, M., Cabanne-Giuli, E. \& Balandreau, J. (2001). Detection and activity of insertion sequences in environmental strains of Burkholderia. Environ Microbiol 3, 766-773.

Nasser, R. M., Rahi, A. C., Haddad, M. F., Daoud, Z., Irani-Hakami, N. \& Almawi, W. Y. (2004). Outbreak of Burkholderia cepacia bacteremia traced to contaminated hospital water used for dilution of an alcohol skin antiseptic. Infect Control Hosp Epidemiol 25, 231-239.

Nierman, W. C., DeShazer, D., Kim, H. S. \& 30 other authors (2004), Structural flexibility in the Burkholderia mallei genome. Proc Natl Acad Sci U S A 101, 14246-14251.

Nzula, S., Vandamme, P. \& Govan, J. R. (2002). Influence of taxonomic status on the in vitro antimicrobial susceptibility of the Burkholderia cepacia complex. J Antimicrob Chemother 50, 265269.

Ortega, X., Hunt, T. A., Loutet, S., Vinion-Dubiel, A. D., Datta, A., Choudhury, B., Goldberg, J. B., Carlson, R. \& Valvano, M. (2005). Reconstitution of O-specific lipopolysaccharide expression in Burkholderia cenocepacia strain J2315, which is associated with transmissible infections in patients with cystic fibrosis. J Bacteriol 187, 1324-1333.

Reynolds, A. E., Felton, J. \& Wright, A. (1981). Insertion of DNA activates the cryptic bgl operon in E. coli K12. Nature 293, 625-629.

Sambrook, J., Fritsch, E. F. \& Maniatis, T. (1989). Molecular Cloning: a Laboratory Manual, 2nd edn. Cold Spring Harbor, NY: Cold Spring Harbor Laboratory.

Scordilis, G. E., Ree, H. \& Lessie, T. G. (1987). Identification of transposable elements which activate gene expression in Pseudomonas cepacia. J Bacteriol 169, 8-13.

Sirinavin, S., Techasaensiri, C., Pakakasama, S., Vorachit, M. Pornkul, R. \& Wacharasin, R. (2004). Hemophagocytic syndrome and Burkholderia cepacia splenic microabscesses in a child with chronic granulomatous disease. Pediatr Infect Dis J 23, 882-884

Summer, E. J., Gonzalez, C. F., Carlisle, T., Mebane, L. M., Cass A. M., Savva, C. G., LiPuma, J. \& Young, R. (2004). Burkholderia cenocepacia phage BcepMu and a family of $\mathrm{Mu}$-like phages encoding potential pathogenesis factors. J Mol Biol 340, 49-65.

Tyler, S. D., Rozee, K. R. \& Johnson, W. M. (1996). Identification of IS1356, a new insertion sequence, and its association with IS402 in epidemic strains of Burkholderia cepacia infecting cystic fibrosis patients. J Clin Microbiol 34, 1610-1616.

Winstanley, C., Detsika, M. G., Glendenning, K. J., Parsons, Y. N. \& Hart, C. A. (2001). Flagellin gene PCR-RFLP analysis of a panel of strains from the Burkholderia cepacia complex. J Med Microbiol 50, 728-731.

Wood, M. S., Byrne, A. \& Lessie, T. G. (1991). IS406 and IS407, two gene-activating insertion sequences for Pseudomonas cepacia. Gene 105, 101-105.

Yesilkaya, H., Thomson, A., Doig, C., Watt, B., Dale, J. W. \& Forbes, K. J. (2003). Locating transposable element polymorphisms in bacterial genomes. J Microbiol Methods 53, 355-363. 